\title{
RESEÑAS
}





\section{Francisco Rodríguez Cascante (Ed.). Obra Literaria de Corina Rodríguez López (poesía, narrativa y ensayo). San José: Editorial de la Universidad de Costa Rica, 2018, 150 páginas}

Como su título lo indica, este libro examina la obra de la escritora costarricense Corina Rodríguez López, quien dejó sus escritos disgregados en diversos periódicos y revistas de su época. Francisco Rodríguez Cascante, el editor, hubo de seguirle el rastro a sus escritos en publicaciones como El Ramonense, Sparti, Unidad y, especialmente, Repertorio Americano, en el cual Rodríguez López fue una asidua colaboradora.

El libro inicia con una breve semblanza de la escritora seguida de un estudio introductorio titulado "Corina Rodríguez López: la Densidad Poética y la Defensa de la Libertad”. Dicho estudio se encuentra debidamente documentado e incluye una nutrida bibliografía; de la misma manera, se presenta una serie de datos autobiográficos y comentarios sobre los textos, los cuales el editor ha organizado por género, a saber: Poesía, Relatos y Ensayos.

Al adentrarse en su obra, se hace evidente que la escritora poseía un espíritu innovador en sus escritos, así como también en su personalidad. Ella hacía poco caso de los convencionalismos de su época con respecto a la métrica y al uso del lenguaje. Creaba su propia voz lírica y su propio discurso, alejándose de lo ordinario y llenando sus textos de imágenes y alusiones. Es por eso que el editor, comentando su poesía en el Estudio Introductorio, dice de Rodríguez López: "La construcción del poema es un ejercicio sumamente cuidadoso regido por la abundancia metafórica, la plenitud imaginativa y la prosa poética, comparable con las mejores manifestaciones hispanoamericanas del posmodernismo, por ejemplo, los textos de Alfonsina Storni y Gabriela Mistral" (xvii).

En efecto, observando su poesía se nota que presenta originalidad en la manera de tratar temas tradicionales a pesar de que a veces se observan marcados ecos de la obra de Gabriela Mistral. Su poema "Meciendo a mi hijo" pone en evidencia este aspecto, ya que el título mismo remite de inmediato al poema "Meciendo" de Mistral. Sin embargo, hay una diferencia notable en el acercamiento al núcleo temático de los dos poemas, la maternidad. El verso de Rodríguez López se centra en las profundas sensaciones de amor y ternura que siente la madre al tener a su hijo en el regazo. La atención del receptor se dirige a las dos figuras, la madre y el niño, que juntas forman una sola imagen. Así da fin al poema la voz poética: "Una ternura inmensa llena todo mi ser cuando tengo en mi regazo mi niño dormido" (48). Por el contrario, en el poema de Gabriela Mistral interviene fuertemente la naturaleza en el acto de mecer, capturando la atención del lector; la imagen de la madre parece estar subordinada a la naturaleza primero y luego a Dios. El viento mece y entonces la gran figura de Dios surge al final meciendo todo el universo así: "Dios Padre sus miles de mundos mece sin ruido / Sintiendo su mano en la sombra / mezo a mi niño" [Anderson Imbert, E. y Florit, E. (Eds.). (1960). Literatura Hispanoamericana: Antología e Introducción Histórica. New York: Holt, Rinehart and Winston., p. 573)]. En el poema de Corina también surge la naturaleza, pero está subordinada a la inmensa imagen del niño mediante una metáfora muy acertada: "Tus ojos [son] las estrellas y los soles de mi mundo interno" (48).

En otros poemas, la temática de la maternidad también ocupa un lugar privilegiado en los versos de Rodríguez López, pero esta aparece elaborada de una manera bastante original. 
Este tema parece desarrollarse apuntando a tres etapas del proceso de llegar a ser madre. A veces se intuye que la voz poética está en espera del gran advenimiento, aún en el proceso de la gestación, luego surge la experiencia del alumbramiento y con más frecuencia en otros poemas se contempla la satisfacción emocional de la madre al tener el niño ya consigo. Esta última etapa se observa plenamente en el poema citado, "Meciendo a mi hijo". El período de gestación se presiente en varios de los versos que apuntan hacia el porvenir, tales como en "Dolor" (22), poema en el cual las ideas se proyectan hacia el futuro. "Tengo una pena muy honda de no haber cultivado más mi espíritu. Sé que no lo encontrarás plenamente digno de ti” (220), dice la hablante poética, dirigiéndose al hijo que espera. Ella no se siente capaz de satisfacer las expectativas que el pequeño pueda tener. La misma proyección hacia el futuro se vislumbra en "Presentimiento", cuando se escucha: "Presiento que serás el incentivo constante hacia la lucha por los nobles ideales de la raza y el espíritu" (23). En este verso se asoman anhelos de justicia social, un tema que también prevalece en la obra de Corina Rodríguez López (xxviii).

En cuanto al proceso del alumbramiento, este evento aparece plenamente claro en el poema homónimo. Se inicia aludiendo a la conmoción que tiene lugar en todo el ser cuando empiezan a manifestarse las primeras señales del parto: "Ya llegas. Ya siento en cada fibra de mi cuerpo un estremecimiento" (45), y luego, refiriéndose a la intensidad del dolor, exclama "Estos espasmos y este crujir de los huesos; esta proximidad de la muerte" (45), indicando así que es tanto el dolor que le parece estar a punto de caer en manos de Tánatos. Y el dolor continúa sin tregua: "Siento que las arterias se van a romper, y que la sangre fluye, y las fuerzas se acaban. El alumbramiento precede un sueño semejante al de la muerte" (45), dice al terminar el verso con otra alusión a la muerte.

Dada la manera en que esta escritora parece desarrollar el tema de la maternidad, se puede deducir que ella buscaba medios que la orientaran hacia la originalidad, aun cuando abordara en sus escritos temas tradicionalmente tratados.

Los textos incluidos en la sección de "Relatos" revelan que Corina Rodríguez López se complacía en rememorar en sus escritos eventos vivenciales significativos. Un ejemplo de este aspecto se aprecia en el trozo titulado "La virgen de la caja blanca", el cual el editor, en su Estudio Introductorio, clasifica como "texto híbrido entre el relato, la poesía en prosa y la biografía ensayística" (xxiv), ya que surgió del dolor sentido a causa de la muerte de una joven compañera de la Escuela Normal (xxiv). Es un texto saturado de sentimientos de amor y de tristeza que envuelven no solo a la hablante poética sino que se extienden abarcando la multitud juvenil que se encuentra en el desfile fúnebre que va hacia el cementerio. "Su espíritu, de un silencio celeste, amó la belleza, diosa inmortal, y por eso silenciosos iban, y la virgen estaba muy risueña" (53). Este texto tiene algunos toques de la primera etapa del modernismo tales como el uso especial de la sinestesia, cierta alusión a los colores y la admiración a lo bello. Sin embargo, es tal vez el espíritu del trozo el que especialmente produzca esa sensación. En efecto, este trozo, por la sentida expresión del dolor ante la pérdida de una joven bella cuya expresión se logra mediante una prosa llena de poesía, remite al poema "Gratia plena" de Amado Nervo, inspirado por la pérdida de su Ana, su "Amada Inmóvil" [Gómez Gil, O. (1968). Historia Crítica de la Literatura Hispanoamericana. New York: Holt, Rinehart and Winston., pp. 430-431). "La caja blanca" por su dimensión afectiva y las alusiones a la belleza virginal de la joven que ha muerto, trae a la mente la reiteración de los sentidos versos de Amado Nervo "Era llena de gracia, como el Avemaría; / ¡Quien la vio no la pudo ya jamás 
olvidar!" (Anderson Imbert, E. y Florit, E. (Eds.). (1960). Literatura Hispanoamericana: Antología e Introducción Histórica. New York: Holt, Rinehart and Winston., p. 486). "La caja blanca" constituye en verdad un texto de naturaleza híbrida, rico en expresiones de tristeza y sentimientos puros.

La sección de "Ensayos" contiene textos que denotan un temperamento apasionado que se vierte en una prosa a veces altisonante, prolífica en la producción de metáforas arriesgadas y adjetivos en abundancia. Es un lenguaje que a veces se torna hiperbólico y aparece rico en alusiones a las lecturas multiculturales de la escritora. Varios de los ensayos se dedican a personajes célebres a quienes ella admira y respeta. A "García Monge" lo considera "una fuerza dinámica" (85) que le volvió la vida a la Biblioteca Nacional, la cual solía ser una momia. Sin embargo, gracias a Don Joaquín García Monge "La momia parece ahora una mujer joven, vigorosa, llena de sangre, ligera de pies, alada, alegre y amable con todos y deseosa de entrar en todas las casas" (85). En cuanto a la voz de este prócer costarricense, ella dice que "Su voz es paternal dentro del aula, es rayo y tempestad en el momento en que el servilismo y la cobardía reducen a los hombres a la calidad de esclavos, es música cuando lee al Marqués de Santillana y a Garcilaso" (89).

Esta edición de las obras de Corina Rodríguez López incluye un segmento del extenso ensayo que preparó la escritora con motivo a la muerte prematura del Dr. Ricardo Moreno Cañas, ocurrida, como apunta la escritora, "por una mano artera" (107). Como es de esperar, la sección del ensayo incluida aparece repleta de alabanzas, trayendo a colación las múltiples cualidades que poseía este médico. Su carrera había seguido siempre una "trayectoria luminosa" (110), aunque él "[no] trató jamás de aparecer como un pontífice, ni como un Catón y cubrió siempre de simpatía las flaquezas humanas; pero fue duro con los que menoscababan la hacienda pública" (109) y "con su verbo candente [defendía] los intereses de los trabajadores" (109). Ante tantos elogios, el lector de hoy se verá obligado a concluir que los funerales de este singular médico habrán sido una verdadera apoteosis. Y así fue, la escritora lo explica a través de una enumeración poéticamente elaborada donde describe detalladamente la reacción de la gente que procede de todos los senderos de la vida. Así dice:

\footnotetext{
Al saber su muerte, el corazón impulsó al jornalero

a dejar su machete; al boyero a desenyugar sus bueyes

y a dejar la carreta policromada en el viejo corredor;

al maestro a transformar la lección, al abogado a darle

tregua al litigio pendiente, $\mathrm{y}$ al negociante, a hacer

un paréntesis en su vida comercial para considerar

la pérdida que había tenido Costa Rica (108).
}

Es evidente que la escritora elabora un ensayo apasionado y, por ende, memorable para dejar la historia del Dr. Moreno Cañas grabada en la mente de la posteridad.

El editor de la Obra Literaria de Corina Rodríguez López ha realizado una admirable labor de rescate e investigación al recoger en un solo volumen los trabajos que andaban distribuidos en diferentes medios de publicación. Este volumen servirá para estudiar más su producción literaria y evaluar justamente a esta escritora, con el fin de hacer patente que es digna de ocupar el lugar que merece en la historia de la literatura de Costa Rica.

Cida S. Chase

Oklahoma State University

Stillwater, Oklahoma, Estados Unidos 